\title{
Cancer Stem Cells in Breast: Current Opinion and Future Challenges
}

\author{
Emmanuelle Charafe-Jauffret ${ }^{\mathrm{a}-\mathrm{c}}$ Florence Monville ${ }^{\mathrm{a}}$ Christophe Ginestier $^{\mathrm{d}}$ \\ Gabriela Dontu $^{d}$ Daniel Birnbaum ${ }^{a}$ Max S. Wicha ${ }^{d}$ \\ ${ }^{a}$ Département d'Oncologie Moléculaire, Centre de Recherche en Cancérologie de Marseille, ${ }^{b}$ Département de \\ Biopathologie, Institut Paoli-Calmettes and UMR891 Inserm and ${ }^{C}$ Faculté de Médecine, Université de la \\ Méditerranée, Marseille, France; ${ }^{\mathrm{d}}$ Division of Hematology/Oncology, Department of Internal Medicine, \\ Comprehensive Cancer Center, University of Michigan Medical Center, Ann Arbor, Mich., USA
}

\section{Key Words}

Breast cancer · Stem cell · Targeted therapy · Aldehyde dehydrogenase

\begin{abstract}
There is increasing evidence for the cancer stem cell hypothesis, which holds that cancers are driven by a cellular subcomponent that has stem cell properties, that is, self-renewal, tumorigenicity and multilineage differentiation capacity. The cancer stem cell hypothesis modifies our conceptual approach of oncogenesis and shall have implications in breast cancer prevention, detection and treatment, especially in metastatic breast cancer for which no curative treatment exists. Given the specific stem cell features, novel therapeutic pathways can be targeted. Following this approach, new molecules are currently in development. Focusing on the cross-talk between stem cells and their microenvironment is also a promising way to explore how to better target cancer stem cells and be curative.

Copyright $\odot 2008$ S. Karger AG, Basel
\end{abstract}

Daniel Birnbaum and Max S. Wicha contributed equally.

\section{Introduction}

About 10 years ago, John Dick's team provided evidence that leukemia growth and propagation are driven by a small population of leukemia cells that have the ability to perpetually self-renew. They called this cell population cancer stem cells (CSC) [1]. Since then, putative CSC have been isolated from many other tumors including breast, brain, colon, pancreas, prostate, lung and head and neck tumors [2-9].

The development and evolution of the mammary gland suggest that stem cells play a pivotal role in the biology of this organ. Indeed, the mammary gland is a unique organ in that it undergoes most of its development after birth and follows the genital events during all life. To achieve this great plasticity and the large cell number expansion associated with it, a considerable number of adult breast stem cells are required. It is tempting to speculate that this fact renders the mammary gland particularly prone to carcinogenesis and that adult breast stem cells play a very important role in breast cancer.

CSC display particular and 'dangerous' features that can have fundamental implications for breast cancer detection, prevention and treatment. Among other things,

Emmanuelle Charafe-Jauffret

Département d'Oncologie Moléculaire, Institut Paoli-Calmettes

UMR891 Inserm, 232, Bd Sainte-Marguerite

FR-13273 Marseille Cedex 09 (France)

Tel. +33 491225 457, Fax +33 491223 573, E-Mail jauffrete@marseille.fnclcc.fr 
CSC foster blood vessel formation, promote cell motility as well as resistance to a variety of therapies [10], and are implicated in breast metastasis $[11,12]$. The link with metastasis is of special clinical relevance, given the evolution of mortality in breast cancer. Although the overall mortality for some of the most common epithelial malignancy including breast cancer has recently been declining, the survival of patients with metastatic disease has not changed significantly over the past several decades. In a recent study [11], cells with a 'stem phenotype' were found in all disseminated tumor cells in the bone marrow. In addition to the putative therapeutic resistance of the CSC, these findings offer new clues for understanding the bad outcome of metastatic breast cancer. As our ability to attack specific pathways altered in cancer increases, the fundamental question remains: Are we targeting the right cells? Hopes for new treatments that selectively kill these cancer seeds come from recent work uncovering the signaling pathways that control CSC proliferation [13].

In breast cancer, the discovery of tumor cells that behave like stem cells offers a possible explanation why cancer may be so difficult to eradicate and suggests how new therapies might be targeted.

In this review, we will discuss the implications that the CSC hypothesis may have on our basic understanding of oncogenesis, as well as the implications for developing new therapies.

\section{The CSC Hypothesis and Conceptual Implications}

All tissues in the body are derived from organ-specific stem cells that are defined by their capacity to undergo self-renewal as well as differentiation into the cell types that comprise each organ. These cells maintain tissue integrity.

According to the CSC hypothesis, in the breast as well as in other tissues, cancer arises from normal stem cells that undergo oncogenic transformation. Cancer-causing mutations can also strike more developmentally advanced, although still immature, early progenitor cells [14]. Recent work provided support for this idea, based on the features of gene fusions found in human acute myeloid leukemia. A fusion protein called MLL-AF9 was genetically engineered in granulocyte-macrophage progenitor cells and transplanted into mice where it generated leukemia similar to acute myeloid leukemia. Isolation of the leukemia stem cells from these mice showed that they resembled the original granulocyte-macrophage progenitors, but had activated genes needed for self- renewal [15]. In solid tumors, stem cells of a given type of cancer may arise from different cells [16].

The CSC hypothesis implies a paradigm shift in thinking about oncogenesis [17]. In contrast to the 'stochastic' model of oncogenesis where transformation results from random mutations and subsequent clonal selection, in this model, cancer originates in tissue stem or progenitors cells probably through dysregulation of self-renewal pathways. This leads to expansion of this cell population that may undergo additional genetic and epigenetic changes. The nature of these genetic and epigenetic changes, and the type of progenitor they target, probably contribute to the cellular heterogeneity found in tumors.

In the normal breast, stem cell differentiation generates organ-specific cell lineages: ductal luminal, myoepithelial and alveolar epithelial cells. In breast cancer, it is assumed that CSC can generate cells with a certain type of aberrant and limited differentiation, which somehow translate into breast molecular subtypes [18]. Epigenetic changes can influence this abnormal tumor differentiation through the niche where the cells grow. In addition, tumor differentiation may also be influenced by the cell of origin (stem cell or progenitor) and the oncogenic events that occurred (the mutation that initiated the transformation and the additional events that followed this initial event). To understand how the CSC hypothesis can be integrated in the new molecular taxonomy of breast cancer and how it can at least partially explain breast cancer heterogeneity is an important challenge [19]. Mouse mammary gland research gives clues to improve this knowledge.

In the mouse mammary gland, stem cells have been isolated and characterized. Stingl et al. [20] recently reported the use of multiparameter cell sorting to purify a rare subset of adult mouse mammary stem cells that are able individually to regenerate an entire mammary gland within 6 weeks in vivo. These cells, sorted as $\mathrm{CD} 45^{-}$ Ter119- CD $31^{-}$Sca- $1^{\text {low }}$ CD24 $4^{\text {med }}$ CD $49 f^{\text {high }}$ cell population, were designated as mammary repopulating unit and expressed markers associated with basal/myoepithelial cells (keratin 5 and 14, smooth muscle actin, vimentin and smooth muscle myosin). They differed from progenitor cells that represented the mammary colony-forming cells and expressed higher level of luminal transcripts (keratin 8,18 and 19 as well as casein) and keratin 6 protein [20]. Stingl et al. [20] thus reported that mouse mammary sorted breast stem cells express basal markers. By analyzing transplants, Regan and Smalley [21] showed that mouse mammary stem cells are found in the basal/myoepithelial compartment (CD24 ${ }^{\text {low }} / \mathrm{Sca}-1^{-} /$Promi- 
nin- $1^{-}$), whereas in vitro colony progenitors are found in the luminal compartment. This luminal compartment could be split into estrogen receptor-positive (ER+) and ER-negative (ER-) cells and contain very few transplantable cells [22]. The ER- CD24 $4^{\mathrm{high}} / \mathrm{Sca}-1^{-} /$Prominin $^{-1}$ population expressed milk proteins and contained the highest number of in vitro colony-forming cells. The ER+ CD $24^{\text {high }} / \mathrm{Sca}-1^{+} /$Prominin $-1^{+}$cells expressed prolactin and progesterone receptor and more luminal cytokeratins than the ER- luminal cells. This compartment forms a differentiated hormone-sensing compartment that stimulates proliferation of basal stem cells and luminal transit amplifying or progenitor cells in a paracrine manner. The transcription factor GATA3, essential in mammary morphogenesis both in embryo and adult mice, is a critical regulator of luminal differentiation [23].

Boecker and colleagues first described heterogenous populations in the normal human adult mammary gland $[24,25]$. Using immunofluorescence for basal cy tokeratin 5 , glandular cytokeratins $8 / 18$ or myoepithelial smooth muscle actin, they identified progenitor cells of glandular/luminal and myoepithelial cell lineages [24]. They proposed that different cellular subgroups in the mammary gland give rise to subgroups of breast carcinomas with differing protein expression and cytogenetic alterations that may be related to clinical behavior [26]. Before a classification based on gene expression profiling was published [27], they first proposed a classification of breast carcinomas based on cytokeratin expression with clinical impact $[25,26]$. These data have been validated by many groups all around the world concerning the impact of cytokeratin-based classification on prognosis and taxonomy of breast cancer [28-33]. Recently, they further proposed that vimentin-expressing carcinomas derive from breast progenitor cells with bipotent (glandular and myoepithelial) differentiation capacity [34].

When all data are taken together, it may be hypothesized that in some cases of breast cancer such as basal breast cancer, there is a 'block' in differentiation, where most cells constituting the bulk of the tumor are not differentiated cells $[19,32,33]$. Basal breast tumors are the most stem-like cells, mainly composed of cells expressing the cancer stem cell marker CD44 ${ }^{+}$[35-37] and cytokeratin $5 / 6$. Basal breast tumors are generally associated with poor outcome. The other subtype with bad outcome is the ERBB2-like breast cancer.

Recent work from our group (presented this year at the annual meeting of the American Association for Cancer Research) suggests a strong link between ERBB2-like tumors and stem cells. We reported that modulation of sig- naling molecules such as phosphatase and tensin homolog on chromosome 10 (PTEN) or ERBB2 can increase the size of the stem cell population. Boosting the expression of the ERBB2 oncogene at the same time as reducing the expression of the PTEN tumor suppressor gene can have additional effects on expanding the stem cell population [13].

A better characterization of CSC that initiate and drive tumor growth, evolution and response to therapy appears more than ever an essential step to improve breast cancer knowledge and management [38]. In addition to providing a basis to an integrated (cellular and molecular) taxonomy of breast cancer, the characterization of CSC calls for therapeutic changes.

\section{Purification and Isolation of CSC}

To isolate and purify the stem cell component of a tumor is a great challenge. The following section will present some of the current ways to achieve this goal, also resumed in figure 1 . The different methods can be categorized into general methods based on intrinsic stem cells features, supposed to be universal across tissues and organs, and tissue-specific methods often based on tissue-restricted properties that can vary depending on the organ considered.

\section{Side Population Technique}

This method is based on the overexpression of transmembrane transporters, like the ATP-binding cassette molecules $A B C G 2 / B C R P 1$. In stem cells, these molecules exclude vital dyes such as Hoechst 33342 or rhodamine 123 from the cells, a property not found in differentiated cells that remain positive for the dye. A side population has been isolated from the breast cancer cell line MCF7, representing $2 \%$ of the total cell line and containing the only tumorigenic fraction from MCF7, as demonstrated by transplantation experiments in NOD/SCID mice xenografts. This fraction is also able to reconstitute the initial heterogeneity of the cell line $[39,40]$.

\section{Tumorospheres}

This is a cell culture technique adapted for breast tumoral tissue based on the mammosphere culture, which was used to isolate and expand stem/progenitor cells from normal breast by our group [41]. Tumorospheres generated in vitro by breast cancer cells are enriched in stem/progenitor cells, as shown by the increase in SP fraction and in CD $44^{+} \mathrm{CD} 24^{-/ \text {low }}$ lin $^{-}$cells [42]. This 


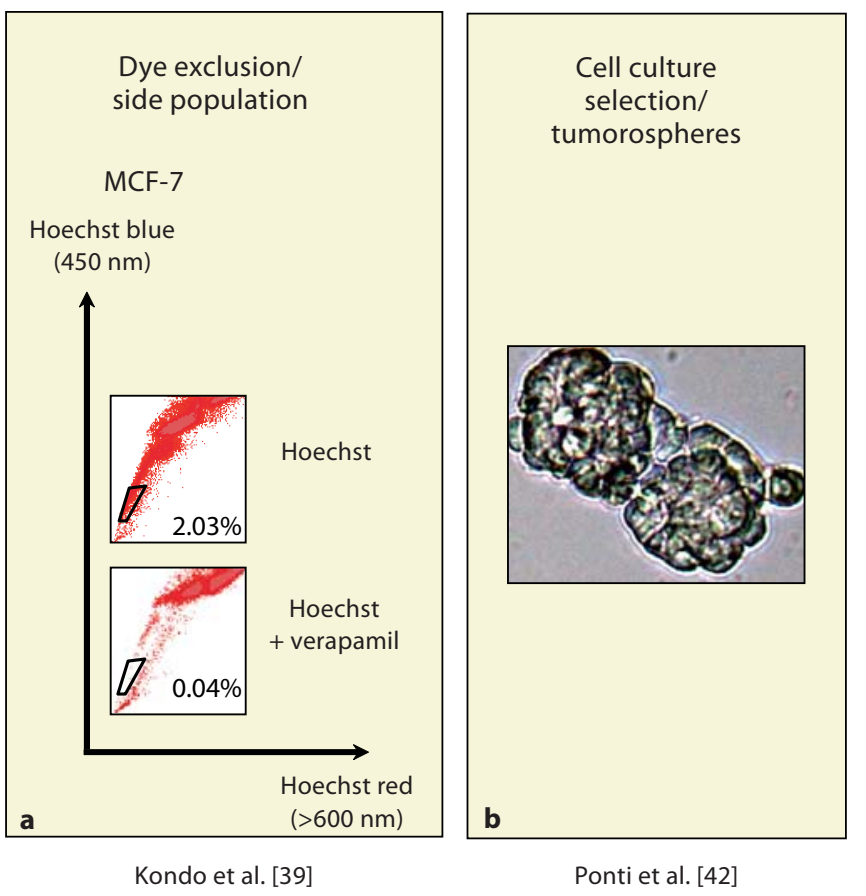

Fig. 1. Purification and isolation techniques of breast CSC. a Side population technique in MCF7 cell line. Stem cells exclude Hoechst 33342 through their overexpression of transmembrane ATP-binding cassette molecules (upper graph). These cells do not exclude Hoechst in presence of verapamil, an ATP-binding cassette protein inhibitor (lower graph). b Tumorosphere technique in MCF7 cell line. Only stem cells are able to survive and proliferate in nonadherent and serum-free culture conditions. Stem cells from tumorospheres are enriched in stem and progenitor cells.

technique is based on the unique property of stem/progenitor cells to survive and grow in serum-free suspension, while more differentiated cells undergo anoikis and die in these conditions.

\section{The $\mathrm{CD} 44^{+} \mathrm{CD} 24^{- \text {llow }}$ Lin $^{-}$Phenotype}

The growing interest in solid CSC began in 2003 when CSC were prospectively isolated from breast tumors [43]. We identified a population of cells that displayed CSC features. This population was defined by the expression of cell surface markers (CD44 $\left.{ }^{+} \mathrm{CD} 24^{-/ \mathrm{low}} \mathrm{lin}^{-}\right)$. As few as 200 of these cells were able to form tumors in NOD/SCID mice, whereas 20,000 cells that did not display this phenotype failed to do so. The tumors formed in mice comprised the entire phenotypical heterogeneity of the initial tumor. The $\mathrm{CD} 44^{+} \mathrm{CD} 24^{-/ \mathrm{low}} \mathrm{lin}^{-}$population from these tumors was able to reinitiate tumors by xenotransplantation in NOD/SCID mice. This behavior indicated that they were able to self-renew and differentiate, and that
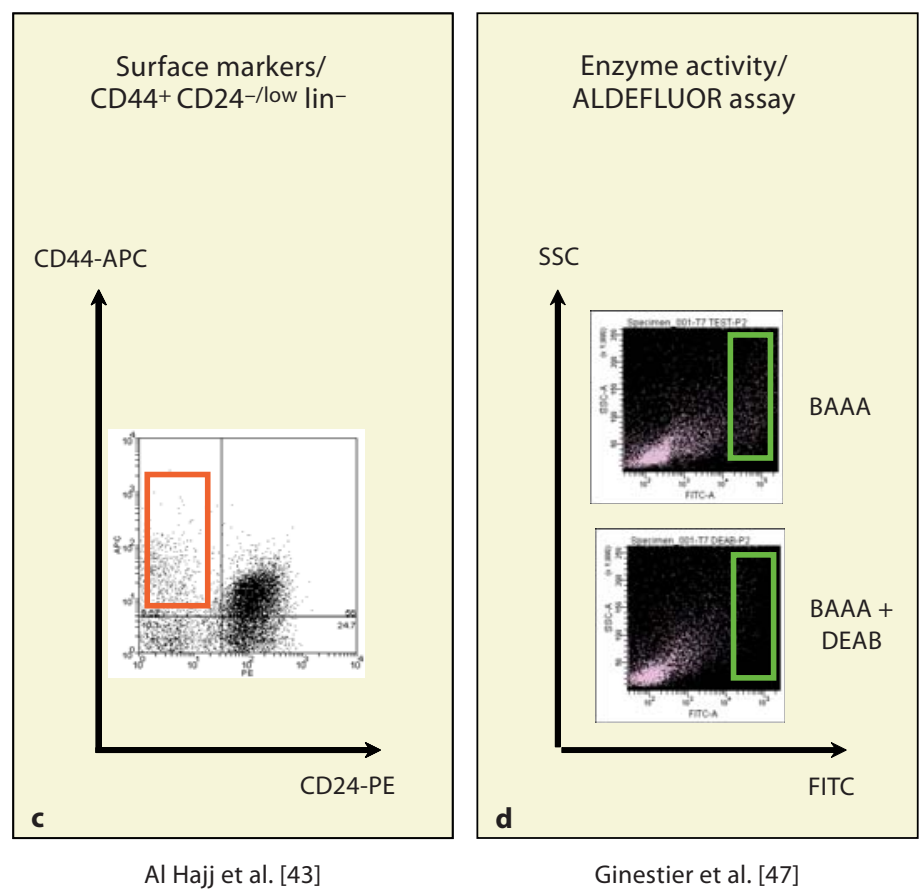

c Immunosorting on CD $44^{+} \mathrm{CD} 24^{-/ \text {low }}$ lin $^{-}$phenotype. CSC are included in the rectangle. $\mathbf{d}$ ALDEFLUOR assay on a breast tumor. Stem cells need ALDH activity to initiate differentiation. The ALDEFLUOR technique allows to sort cells with high ALDH enzymatic activity adding a substrate of this enzyme (BAAA), metabolized in a green fluorescent product in ALDH1-positive cells (rectangle, upper graph). These cells do not metabolize the substrate in the presence of DEAB, an inhibitor of ALDH (lower graph).

they were the tumorigenic population of the tumors, therefore presenting CSC features. CD44 appears to be a shared stem cell marker, common to different organs and pathologies $[8,16,44]$, as well as a promising therapeutic target $[45,46]$. The $\mathrm{CD} 44^{+} \mathrm{CD} 24^{-/ \text {low }}$ lin $^{-}$phenotype, however, is probably tissue restricted. For example, in pancreatic tumors, a stem cell population with the CD $44^{+}$ $\mathrm{CD} 24^{-/ \text {low }} \operatorname{lin}^{+}$phenotype [7] was isolated. Another limitation, even within breast tumors, should be the heterogeneity of this population that does not contain all breast CSC. For example, the overlap with ALDEFLUOR-positive population shown to contain breast CSC is very small [47].

\section{Aldehyde Dehydrogenase}

This method has been recently used to isolate stem and progenitor cells from the normal and tumoral breast. It is based on enzymatic activity of aldehyde dehydrogenase 1 (ALDH1), a detoxifying enzyme responsible for 
the oxidation of intracellular aldehydes, which may have a role in early differentiation of stem cells through its role in oxidizing retinol to retinoic acid $[48,49]$. This approach is based on conserved stem and progenitor cell functions that may also be inherited by the malignant stem cell compartment, across multiple histologic subtypes of cancer from the same tissue of origin.

Cells that have high ALDH activity have been associated with several types of murine and human stem hematopoietic cells as well as neural stem and progenitor cells [50-54]. ALDH activity, detected by the ALDEFLUOR assay, may provide a common marker for both normal and malignant stem and progenitor cells. It was successfully used to isolate stem cells from leukemia and multiple myeloma [54].

Our recent study demonstrated that ALDEFLUORpositive cells isolated from both normal and tumoral human breast have phenotypic and functional characteristics of mammary stem cells. Furthermore, the ALDEFLUOR-positive population isolated from human breast tumors contains CSC as demonstrated by the ability of these cells, but not ALDEFLUOR-negative cells, to generate tumors in NOD/SCID mice. Serial passages of ALDEFLUOR-positive cells generate tumors recapitulating the phenotypical diversity of the initial tumor. In situ staining in formalin-fixed, paraffin-embedded specimens identified both normal and malignant human mammary stem cells and the analysis of ALDH1 expression in 577 human breast carcinomas from 2 different patient populations showed that the expression of this stem/progenitor cell marker is a powerful predictor of poor clinical outcome [47].

Thus, different methods have been used to isolate and characterize breast CSC. Some are promising, but further validations with combination of 2 or more methods will be necessary to improve our knowledge of the cells that drive tumor growth and evolution.

\section{Therapeutic Implications on Breast Cancer Management}

Most current therapies in breast cancer (surgery, various types of chemotherapy, hormonotherapy, radiotherapy) have shown their efficiency but also their limits. Therapeutic strategies are well validated for breast cancer management. However, therapeutic resistance, underlying recurrence and the lack of curative treatment in metastatic disease, raises the question if current therapies target the right cells.

Cancer Stem Cells in Breast:

Current Opinion and Future Challenges
Intrinsic Resistance of Stem Cells

CSC are likely to share many of the properties of normal stem cells, including relative quiescence, resistance to drugs and toxins through the expression of several $\mathrm{ABC}$ transporters, active DNA repair capacity and resistance to apoptosis. Therefore, tumors might have a builtin population of drug-resistant pluripotent cells that can survive chemotherapy and repopulate the tumor. Stem cells are different from more mature differentiated cells in that they divide infrequently. Thus, antimitotic chemotherapies are less effective in stem cells than in the cells of the bulk of the tumor [55].

One particularly intriguing property of stem cells is that they express high levels of $\mathrm{ABC}$ drug transporters. For example, they express high levels of $A B C G 2$, whereas the gene is turned off in most committed progenitors. The $2 \mathrm{ABC}$ transporter-encoding genes that have been studied most extensively in stem cells are $A B C B 1$, which encodes P-glycoprotein, and $A B C G 2$. Along with $A B C C 1$, they represent the 3 principal multidrug resistance genes that have been identified in tumor cells [56].

As mentioned above, side population identification is based on the activity of the ABC transporter ABCG2/ BCRP1. Drugs that can specifically inhibit this mechanism, such as P-glycoprotein inhibitors, have been tested in clinical trials, but despite some promising results, Pglycoprotein inhibitors have not been successful in breast cancer treatment. The drugs are also active on normal stem cells and the resultant toxicity is high. Polymorphisms in the $A B C G 2$ gene affect the pharmacokinetics of substrate drugs and make these drugs difficult to manage [57].

Stem cells appear to be resistant to radiotherapy. In gliomas, the fraction of tumor cells expressing CD133 (Prominin-1), a marker for both neural stem cells and brain CSC, is enriched after radiation. Tumor stem cells represent the cellular population that confers glioma radioresistance and could be the source of tumor recurrence after radiation. The mechanisms underlying tumor radioresistance have been described. CSC could contribute to glioma radioresistance through preferential activation of the DNA damage checkpoint response and increase in DNA repair capacity. The mechanism of resistance involves the cell cycle-regulating proteins CHEK1 and CHEK2. Targeting DNA damage checkpoint response in CSC may overcome this radioresistance and provide a therapeutic model for malignant brain cancers $[58,59]$.

In the breast cancer cell line MCF7, the CSC-like population bearing the $\mathrm{CD} 44^{+} \mathrm{CD} 24^{-/ \text {low }}$ phenotype shows

Pathobiology 2008;75:75-84 
relative radioresistance. The size of this population increases after short courses of fractionated irradiation. These findings offer a possible mechanism for the accelerated repopulation of tumor cells observed during gaps in radiotherapy [10]. Details of radiobiology of stem-like cells in their native environment within tumors in vivo would confer considerable significance to these findings.

\section{Specific Pathways in Stem Cells}

According to the CSC hypothesis, tumors are driven by cellular components that display stem cell properties. In fact, when CSC divide, one daughter is an exact copy of the original and retains the ability to divide and initiate additional tumors, whereas the other daughter cell differentiates to produce nontumorigenic cells. This asymmetric division is controlled by various pathways that govern stem cell self-renewal and differentiation and control the pool of stem cells.

The Hedgehog $(\mathrm{HH})$ pathway is one of the main pathways that control stem cell fate, self-renewal and maintenance. Inhibition of $\mathrm{HH}$ signaling with cyclopamine, a specific inhibitor, or through lentiviral-mediated silencing demonstrated that the tumorigenicity of human gliomas in mice requires an active $\mathrm{HH}$ pathway. $\mathrm{HH}$ signaling is essential in controlling the behavior of human glioma CSC and represents a new therapeutic target [60].

The $\mathrm{HH}$ pathway is necessary for many developmental processes, including the formation of several epidermal appendages. In the mammary gland, strict regulation of the $\mathrm{HH}$ pathway is required for normal development. Alterations in $\mathrm{HH}$ signaling result in defects in both the embryonic and postnatal mammary gland. Activation of $\mathrm{HH}$ signaling either by mutation or abnormal expression of pathway members can lead to the development and/or progression of cancers in multiple organs [61].

The role of the HH pathway in the stem cells of the normal and tumoral breast has been documented by our group. Our studies support a CSC model in which the $\mathrm{HH}$ pathway and the polycomb protein BMI1 play important roles in regulating self-renewal of normal and tumorigenic human mammary stem cells [62].

$\mathrm{HH}$ pathway components PTCH1, GLI1 and GLI2 are highly expressed in normal human mammary stem/progenitor cells cultured as mammospheres, but are downregulated when cells differentiate. Activation of $\mathrm{HH}$ signaling increases the number of mammosphere-initiating cells and mammosphere size, whereas inhibition of the pathway results in a reduction of these parameters. These effects are mediated by BMI1. Overexpression of GLI2 in mammosphere-initiating cells results in the production of ductal hyperplasia. Modulation of BMI1 expression in mammosphere-initiating cells alters the generation of mammary outgrowths in vivo in a humanized NOD/ SCID mouse model. Furthermore, we showed that the $\mathrm{HH}$ signaling pathway is activated in human breast CSC defined as CD $44^{+} \mathrm{CD} 24^{-/ \text {low }}$ lin $^{-}$cells. All these data highlight potential of developing a novel anticancer therapy based on blocking the $\mathrm{HH}$ pathway.

\section{NOTCH Pathway}

A role for NOTCH signaling in human breast cancer has been suggested by both the development of adenocarcinomas in the murine mammary gland following constitutive pathway activation and the loss of NUMB expression, a negative regulator of the NOTCH pathway, in a large proportion of breast carcinomas. The accumulation of the intracellular domain of NOTCH1 and hence increased NOTCH signaling in a wide variety of human breast carcinomas was also documented [63]. NOTCH1 and NOTCH4 are involved in normal development of the mammary gland, and mutated forms of these genes are associated with the development of mouse mammary tumors. We demonstrated that induction of NOTCH signaling promotes self-renewal of normal human mammary stem cells. We observed a 10 -fold increase in secondary mammosphere formation after treatment with a synthetic peptide, DSL (Delta/serrate/Lag-2), which can activate the NOTCH pathway. Activation of this pathway also increased branching morphogenesis in three-dimensional Matrigel culture. These effects were blocked by an anti$\mathrm{NOTCH}$ antibody or a $\gamma$-secretase inhibitor, suggesting a specific requirement of $\mathrm{NOTCH}$ in these signaling events [64]. In medulloblastomas and acute $\mathrm{T}$ cell lymphoid leukemia, inhibitors of the $\gamma$-secretase complex deplete stem cells and slow the growth of NOTCH-dependent tumors $[65,66]$. The mTOR pathway is one of the main downstream pathways that transmit prooncogenic signals of the NOTCH pathway. Simultaneous treatment with the mTOR inhibitor rapamycin and $\gamma$-secretase inhibitor in a highly synergistic manner suppressed acute $\mathrm{T}$ cell lymphoid leukemia cell growth, suggesting this would be a successful drug combination for treating this aggressive malignancy [67].

NOTCH pathway deregulation has been implicated in a preinvasive breast lesion, ductal carcinoma in situ (DCIS). Aberrant activation of NOTCH signaling is probably an early event in breast cancer. High expression of 
NOTCH1 intracellular domain (NICD) in DCIS also predicted a reduced time to recurrence, 5 years after surgery. A $\gamma$-secretase inhibitor and a NOTCH4-neutralizing antibody reduced DCIS mammosphere formation, indicating that NOTCH signaling and other stem cell self-renewal pathways may represent novel therapeutic targets to prevent recurrence of preinvasive and invasive breast cancer $[68,69]$.

\section{Other Pathways}

The pathways that regulate self-renewal and cell fate CSC begin to be elucidated. In addition to pathways such as WNT, NOTCH and $\mathrm{HH}$, known to regulate self-renewal of normal stem cells, tumor suppressor genes such as PTEN and TP53 (tumor protein p53) have also been implicated in the regulation of CSC self-renewal. It is believed that these pathways are deregulated in CSC, leading to uncontrolled self-renewal of these cells, which in turn generate tumors that are resistant to conventional therapies [70].

Many different pathways could be implicated in the determination of breast stem cell fate. These pathways may be deregulated in cancer and could hence represent potential pathways to target when developing new therapeutic strategies.

Molecules that can interfere with these pathways can be tested first in vitro on the CSC component within cell lines, and subsequently validated in in vivo animal models bearing xenografted cell lines or patient tumors, or in transgenic mice. Despite the caveats represented by a change in the functional properties of CSC in the animal host and the changes in the niche (tumoral stroma, hormonal influence), the xenograft model of patient samples is the experimental system closest to the tumor in human patients [71].

\section{Stem Cell and the Niche}

The stem cell niche is the microenvironment surrounding stem cells that maintain their stemness and prevents them from differentiating. It comprises stem cells, signaling surrounding cells and characteristic extracellular matrix. The pivotal role of the mammary gland stem cell niche is obvious through the outgrowth and modifications of mammary gland upon hormonal stimulations [72].

Cancer Stem Cells in Breast:

Current Opinion and Future Challenges
The most impressive evidence of the niche dominance was provided by the recent demonstration that it is able to redirect spermatogenic fate. The reprogrammation of adult testicular cells into mammary progenitor cells was obtained following injection of a single-cell suspension of cells from adult seminiferous tubules mixed with mammary epithelial cells, into the cleared mammary fat pad of mice. The reprogrammed testicular cells were able to reconstitute mammary progenitors upon serial transplantation [73]. These results provide evidence for the ascendancy of the tissue microenvironment over the intrinsic nature of cells from an alternative adult tissue. Growth of normal human breast stem cells in a host animal was obtained only in the cleared and humanized fat pad of NOD/SCID mice, indicating that the presence of the human stroma is critical [71].

Another strong demonstration of how tumor microenvironment in the breast facilitates metastatic spread by eliciting reversible changes in the phenotype of cancer cells comes from Weinberg and colleagues [74]. They showed that bone marrow-derived human mesenchymal stem cells mixed with otherwise weakly metastatic human breast carcinoma cells cause the cancer cells to increase their metastatic potency. The breast cancer cells stimulate de novo secretion of the chemokine CCL 5 from mesenchymal stem cells, which then acts in a paracrine fashion on the cancer cells to enhance their motility, invasion and metastatic potential. This metastatic ability is reversible and depends on CCL5 signaling through the chemokine receptor CCR5 [74]. This demonstrates that the niche or microenvironment where stem cells grow can determine stem cell fate and also modify their biological properties, such as invasion and metastatic potential.

\section{A Stem of Caution}

Despite important advances in the CSC field, some skepticism persists. One of the main criticisms is that virtually all the work has involved transplanting human cancer cells into immunodeficient mice. This has raised concerns that the experiments do not accurately reflect what happens during cancer initiation and progression in human patients. The idea that only rare CSC can initiate tumor formation has recently been challenged [75]. In this study, as few as 10 leukemic cells from mice genetically engineered to develop leukemia were injected into genetically compatible healthy animals. As all recipient mice developed leukemia, the authors suggested it could

Pathobiology 2008;75:75-8 
not have happened if only a tiny minority of tumor cells had the ability to initiate tumor formation. They concluded that the mouse does not provide the right environment for the growth of human cancer cells, and questioned the CSC hypothesis.

\section{Conclusion}

Despite these doubts, the CSC model is very attractive. The model suggests that it may be necessary to target and eliminate CSC to eradicate cancers. The use of drugs that interfere with specific stem cell self-renewal is a strategy of choice but a great challenge, since normal and tumoral stem cells share many common pathways. The CSC hypothesis will modify our understanding of breast oncogenesis and provide rational support for classification, detection and prevention. For metastatic breast cancer, the implications are probably wider, since there is no curative treatment for metastatic disease. Recent studies functionally link metastasis, stem cells and cancer survival.

The emphasis is currently on new therapeutic strategies consisting of molecular targeting of distinct oncogenic signaling components activated in the cancer progenitor cells and their local microenvironment during cancer progression. These new targeted therapies should improve the efficacy of current treatments against aggressive cancers, and thereby should prevent disease relapse and enhance patient survival. New strategies need to take into account the role of the microenvironment that can have a critical role in modulating stem cell fate and response to therapeutic agents.

\section{References}

1 Bonnet D, Dick JE: Human acute myeloid leukemia is organized as a hierarchy that originates from a primitive hematopoietic cell. Nat Med 1997;3:730-737.

-2 Anton Aparicio LM, Garcia CR, Cassinello EJ, Valladares AM, Reboredo LM, Diaz PS, Aparicio GG: Prostate cancer and Hedgehog signalling pathway. Clin Transl Oncol 2007; 9:420-428.

- 3 Ceder JA, Jansson L, Ehrnstrom RA, Ronnstrand L, Abrahamsson PA: The characterization of epithelial and stromal subsets of candidate stem/progenitor cells in the human adult prostate. Eur Urol 2008;53:524532.

4 Eramo A, Lotti F, Sette G, Pilozzi E, Biffoni M, Di Virgilio A, Conticello C, Ruco L, Peschle C, De Maria R: Identification and expansion of the tumorigenic lung cancer stem cell population. Cell Death Differ 2008; 15:504-514

5 Ferrandina G, Bonanno G, Pierelli L, Perillo A, Procoli A, Mariotti A, Corallo M, Martinelli E, Rutella S, Paglia A, Zannoni G, Mancuso S, Scambia G: Expression of CD133-1 and CD133-2 in ovarian cancer. Int J Gynecol Cancer 2007, E-pub ahead of print.

6 Glinsky GV: Stem cell origin of death-fromcancer phenotypes of human prostate and breast cancers. Stem Cell Rev 2007;3:79-93.

7 Li C, Heidt DG, Dalerba P, Burant CF, Zhang L, Adsay V, Wicha M, Clarke MF, Simeone DM: Identification of pancreatic cancer stem cells. Cancer Res 2007;67:1030-1037.
8 Prince ME, Sivanandan R, Kaczorowski A, Wolf GT, Kaplan MJ, Dalerba P, Weissman IL, Clarke MF, Ailles LE: Identification of a subpopulation of cells with cancer stem cell properties in head and neck squamous cell carcinoma. Proc Natl Acad Sci USA 2007; 104:973-978.

9 Seo DC, Sung JM, Cho HJ, Yi H, Seo KH, Choi IS, Kim DK, Kim JS, Abd El-Aty AM, Shin HC: Gene expression profiling of cancer stem cell in human lung adenocarcinoma A549 cells. Mol Cancer 2007;6:75.

10 Phillips TM, McBride WH, Pajonk F: The response of CD24 $4^{-/ \text {low }} / \mathrm{CD} 44+$ breast cancerinitiating cells to radiation. J Natl Cancer Inst 2006;98:1777-1785.

11 Balic M, Lin H, Young L, Hawes D, Giuliano A, McNamara G, Datar RH, Cote RJ: Most early disseminated cancer cells detected in bone marrow of breast cancer patients have a putative breast cancer stem cell phenotype. Clin Cancer Res 2006;12:5615-5621.

12 Sheridan C, Kishimoto H, Fuchs RK, Mehrotra S, Bhat-Nakshatri P, Turner $\mathrm{CH}$, Goulet RJr, Badve S, Nakshatri H: CD44+/CD24breast cancer cells exhibit enhanced invasive properties: an early step necessary for metastasis. Breast Cancer Res 2006;8:R59.

13 Korkaya H, Iovino F, Wicha MS: PTEN and HER2 regulate self-renewal and invasion of human mammary stem cells. Proc Annu Meet Am Assoc Cancer Res 2007, abstr 1287.

14 Jaiswal S, Traver D, Miyamoto T, Akashi K, Lagasse E, Weissman IL: Expression of BCR/ $\mathrm{ABL}$ and BCL-2 in myeloid progenitors leads to myeloid leukemias. Proc Natl Acad Sci USA 2003;100:10002-10007.
$D_{15}$ Krivtsov AV, Twomey D, Feng Z, Stubbs MC, Wang Y, Faber J, Levine JE, Wang J, Hahn WC, Gilliland DG, Golub TR, Armstrong SA: Transformation from committed progenitor to leukaemia stem cell initiated by MLL-AF9. Nature 2006;442:818-822.

16 Dalerba P, Dylla SJ, Park IK, Liu R, Wang X, Cho RW, Hoey T, Gurney A, Huang EH, Simeone DM, Shelton AA, Parmiani G, Castelli C, Clarke MF: Phenotypic characterization of human colorectal cancer stem cells. Proc Natl Acad Sci USA 2007;104:1015810163.

17 Wicha MS, Liu S, Dontu G: Cancer stem cells: an old idea - a paradigm shift. Cancer Res 2006;66:1883-1890.

18 Sorlie T, Tibshirani R, Parker J, Hastie T, Marron JS, Nobel A, Deng S, Johnsen H, Pesich R, Geisler S, Demeter J, Perou CM, Lonning PE, Brown PO, Borresen-Dale AL, Botstein D: Repeated observation of breast tumor subtypes in independent gene expression data sets. Proc Natl Acad Sci USA 2003; 100:8418-8423

19 Stingl J, Caldas C: Molecular heterogeneity of breast carcinomas and the cancer stem cell hypothesis. Nat Rev Cancer 2007;7:791799.

20 Stingl J, Eirew P, Ricketson I, Shackleton M, Vaillant F, Choi D, Li HI, Eaves CJ: Purification and unique properties of mammary epithelial stem cells. Nature 2006;439:993-997.

-21 Regan J, Smalley M: Prospective isolation and functional analysis of stem and differentiated cells from the mouse mammary gland. Stem Cell Rev 2007;3:124-136. 
-22 Sleeman KE, Kendrick H, Robertson D, Isacke CM, Ashworth A, Smalley MJ: Dissociation of estrogen receptor expression and in vivo stem cell activity in the mammary gland. J Cell Biol 2007;176:19-26.

-23 Asselin-Labat ML, Sutherland KD, Barker $\mathrm{H}$, Thomas R, Shackleton M, Forrest NC, Hartley L, Robb L, Grosveld FG, van der WJ, Lindeman GJ, Visvader JE: Gata-3 is an essential regulator of mammary-gland morphogenesis and luminal-cell differentiation. Nat Cell Biol 2007;9:201-209.

-24 Boecker W, Buerger H: Evidence of progenitor cells of glandular and myoepithelial cell lineages in the human adult female breast epithelium: a new progenitor (adult stem) cell concept. Cell Prolif 2003;36(suppl 1):73-84.

-25 Nagle RB, Bocker W, Davis JR, Heid HW, Kaufmann M, Lucas DO, Jarasch ED: Characterization of breast carcinomas by two monoclonal antibodies distinguishing myoepithelial from luminal epithelial cells. J Histochem Cytochem 1986;34:869-881.

-26 Korsching E, Packeisen J, Agelopoulos K, Eisenacher M, Voss R, Isola J, van Diest PJ, Brandt B, Boecker W, Buerger H: Cytogenetic alterations and cytokeratin expression patterns in breast cancer: integrating a new model of breast differentiation into cytogenetic pathways of breast carcinogenesis. Lab Invest 2002;82:1525-1533.

-27 Sorlie T, Tibshirani R, Parker J, Hastie T, Marron JS, Nobel A, Deng S, Johnsen H, Pesich R, Geisler S, Demeter J, Perou CM, Lonning PE, Brown PO, Borresen-Dale AL, Botstein D: Repeated observation of breast tumor subtypes in independent gene expression data sets. Proc Natl Acad Sci USA 2003; 100:8418-8423.

-28 Livasy CA, Perou CM, Karaca G, Cowan DW, Maia D, Jackson S, Tse CK, Nyante S, Millikan RC: Identification of a basal-like subtype of breast ductal carcinoma in situ. Hum Pathol 2007;38:197-204.

-29 Rakha EA, Putti TC, Abd El-Rehim DM, Paish C, Green AR, Powe DG, Lee AH, Robertson JF, Ellis IO: Morphological and immunophenotypic analysis of breast carcinomas with basal and myoepithelial differentiation. J Pathol 2006;208:495-506.

-30 Abd El-Rehim DM, Ball G, Pinder SE, Rakha E, Paish C, Robertson JF, Macmillan D, Blamey RW, Ellis IO: High-throughput protein expression analysis using tissue microarray technology of a large well-characterised series identifies biologically distinct classes of breast cancer confirming recent cDNA expression analyses. Int J Cancer 2005;116:340-350.

-31 Laakso M, Tanner M, Nilsson J, Wiklund T, Erikstein B, Kellokumpu-Lehtinen P, Malmstrom P, Wilking N, Bergh J, Isola J: Basoluminal carcinoma: a new biologically and prognostically distinct entity between basal and luminal breast cancer. Clin Cancer Res 2006;12:4185-4191.
32 Charafe-Jauffret E, Chaffanet M, Bertucci F, Ginestier C, Jacquemier J, deLapeyriere $\mathrm{O}$, Birnbaum D: Towards an integrated cellular and molecular: definition of breast cancers. Med Sci (Paris) 2007;23:626-632.

33 Charafe-Jauffret E, Ginestier C, Monville F, Fekairi S, Jacquemier J, Birnbaum D, Bertucci F: How to best classify breast cancer: conventional and novel classifications (review). Int J Oncol 2005;27:1307-1313.

34 Korsching E, Packeisen J, Liedtke C, Hungermann D, Wulfing $\mathrm{P}$, van Diest PJ, Brandt $\mathrm{B}$, Boecker W, Buerger $\mathrm{H}$ : The origin of vimentin expression in invasive breast cancer: epithelial-mesenchymal transition, myoepithelial histogenesis or histogenesis from progenitor cells with bilinear differentiation potential? J Pathol 2005;206:451-457.

35 Shipitsin M, Campbell LL, Argani P, Weremowicz S, Bloushtain-Qimron N, Yao J, Nikolskaya T, Serebryiskaya T, Beroukhim R, Hu M, Halushka MK, Sukumar S, Parker LM, Anderson KS, Harris LN, Garber JE, Richardson AL, Schnitt SJ, Nikolsky Y, Gelman RS, Polyak K: Molecular definition of breast tumor heterogeneity. Cancer Cell 2007;11:259-273.

36 Fulford LG, Reis-Filho JS, Ryder K, Jones C, Gillett CE, Hanby A, Easton D, Lakhani SR: Basal-like grade III invasive ductal carcinoma of the breast: patterns of metastasis and long-term survival. Breast Cancer Res 2007; 9:R4

37 Polyak K: Breast cancer stem cells: a case of mistaken identity? Stem Cell Rev 2007;3: 107-109.

38 Mimeault M, Hauke R, Mehta PP, Batra SK: Recent advances in cancer stem/progenitor cell research: therapeutic implications for overcoming resistance to the most aggressive cancers. J Cell Mol Med 2007;11:981-1011.

39 Kondo T, Setoguchi T, Taga T: Persistence of a small subpopulation of cancer stem-like cells in the C6 glioma cell line. Proc Natl Acad Sci USA 2004;101:781-786.

40 Patrawala L, Calhoun T, Schneider-Broussard R, Zhou J, Claypool K, Tang DG: Side population is enriched in tumorigenic, stemlike cancer cells, whereas ABCG2+ and ABCG2- cancer cells are similarly tumorigenic. Cancer Res 2005;65:6207-6219.

41 Dontu G, Abdallah WM, Foley JM, Jackson KW, Clarke MF, Kawamura MJ, Wicha MS: In vitro propagation and transcriptional profiling of human mammary stem/progenitor cells. Genes Dev 2003;17:1253-1270.

42 Ponti D, Costa A, Zaffaroni N, Pratesi G, Petrangolini G, Coradini D, Pilotti S, Pierotti MA, Daidone MG: Isolation and in vitro propagation of tumorigenic breast cancer cells with stem/progenitor cell properties. Cancer Res 2005;65:5506-5511.

43 Al Hajj M, Wicha MS, Benito-Hernandez A Morrison SJ, Clarke MF: Prospective identification of tumorigenic breast cancer cells Proc Natl Acad Sci USA 2003;100:39833988.
44 Harper LJ, Piper K, Common J, Fortune F, Mackenzie IC: Stem cell patterns in cell lines derived from head and neck squamous cell carcinoma. J Oral Pathol Med 2007;36:594603.

45 Jin L, Hope KJ, Zhai Q, Smadja-Joffe F, Dick JE: Targeting of CD44 eradicates human acute myeloid leukemic stem cells. Nat Med 2006;12:1167-1174.

-46 Subramaniam V, Vincent IR, Gilakjan M, Jothy S: Suppression of human colon cancer tumors in nude mice by siRNA CD44 gene therapy. Exp Mol Pathol 2007;83:332-340.

47 Ginestier C, Hur MH, Charafe-Jauffret E, Monville F, Dutcher J, Brown M, Jacquemier J, Viens P, Kleer CG, Liu S, Schott A, Hayes D, Birnbaum D, Wicha MS, Dontu G: ALDH1 is a marker of normal and malignant human mammary stem cells and a predictor of poor clinical outcome. Cell Stem Cell 2007;1:555567.

48 Duester G: Families of retinoid dehydrogenases regulating vitamin A function: production of visual pigment and retinoic acid. Eur J Biochem 2000;267:4315-4324.

49 Sophos NA, Vasiliou V: Aldehyde dehydrogenase gene superfamily: the 2002 update. Chem Biol Interact 2003;143-144:5-22.

50 Armstrong L, Stojkovic M, Dimmick I, Ahmad S, Stojkovic P, Hole N, Lako M: Phenotypic characterization of murine primitive hematopoietic progenitor cells isolated on basis of aldehyde dehydrogenase activity. Stem Cells 2004;22:1142-1151.

51 Corti S, Locatelli F, Papadimitriou D, Donadoni C, Salani S, Del Bo R, Strazzer S, Bresolin N, Comi GP: Identification of a primitive brain-derived neural stem cell population based on aldehyde dehydrogenase activity. Stem Cells 2006;24:975-985.

$\checkmark 52$ Hess DA, Meyerrose TE, Wirthlin L, Craft TP, Herrbrich PE, Creer MH, Nolta JA: Functional characterization of highly purified human hematopoietic repopulating cells isolated according to aldehyde dehydrogenase activity. Blood 2004;104:16481655 .

53 Hess DA, Wirthlin L, Craft TP, Herrbrich PE, Hohm SA, Lahey R, Eades WC, Creer $\mathrm{MH}$, Nolta JA: Selection based on CD133 and high aldehyde dehydrogenase activity isolates long-term reconstituting human hematopoietic stem cells. Blood 2006;107:21622169.

54 Matsui W, Huff CA, Wang Q, Malehorn MT, Barber J, Tanhehco Y, Smith BD, Civin CI, Jones RJ: Characterization of clonogenic multiple myeloma cells. Blood 2004;103: 2332-2336.

55 Reya T, Morrison SJ, Clarke MF, Weissman IL: Stem cells, cancer, and cancer stem cells. Nature 2001;414:105-111.

56 Dean M, Fojo T, Bates S: Tumour stem cells and drug resistance. Nat Rev Cancer 2005;5: 275-284. 
57 Morisaki K, Robey RW, Ozvegy-Laczka C, Honjo Y, Polgar O, Steadman K, Sarkadi B, Bates SE: Single nucleotide polymorphisms modify the transporter activity of ABCG2. Cancer Chemother Pharmacol 2005;56:161172.

>58 Bao S, Wu Q, McLendon RE, Hao Y, Shi Q, Hjelmeland AB, Dewhirst MW, Bigner DD, Rich JN: Glioma stem cells promote radioresistance by preferential activation of the DNA damage response. Nature 2006;444: 756-760.

-59 Hambardzumyan D, Squatrito M, Holland EC: Radiation resistance and stem-like cells in brain tumors. Cancer Cell 2006;10:454456.

-60 Clement V, Sanchez P, de Tribolet N, Radovanovic I, Altaba A: HEDGEHOG-GLI1 signaling regulates human glioma growth, cancer stem cell self-renewal, and tumorigenicity. Curr Biol 2007; 17:165-172.

-61 Hatsell S, Frost AR: Hedgehog signaling in mammary gland development and breast cancer. J Mammary Gland Biol Neoplasia 2007;12:163-173.

-62 Liu S, Dontu G, Mantle ID, Patel S, Ahn NS, Jackson KW, Suri P, Wicha MS: Hedgehog signaling and Bmi-1 regulate self-renewal of normal and malignant human mammary stem cells. Cancer Res 2006;66:6063-6071.

63 Stylianou S, Clarke RB, Brennan K: Aberrant activation of notch signaling in human breast cancer. Cancer Res 2006;66:15171525.
64 Dontu G, Jackson KW, McNicholas E, Kawamura MJ, Abdallah WM, Wicha MS Role of Notch signaling in cell-fate determination of human mammary stem/progenitor cells. Breast Cancer Res 2004;6:R605-R615.

65 Fan X, Matsui W, Khaki L, Stearns D, Chun J, Li YM, Eberhart CG: Notch pathway inhibition depletes stem-like cells and blocks engraftment in embryonal brain tumors. Cancer Res 2006;66:7445-7452.

66 Weng AP, Millholland JM, Yashiro-Ohtani Y, Arcangeli ML, Lau A, Wai C, Del Bianco C, Rodriguez CG, Sai H, Tobias J, Li Y, Wolfe MS, Shachaf C, Felsher D, Blacklow SC, Pear WS, Aster JC: c-Myc is an important direct target of Notch1 in T-cell acute lymphoblastic leukemia/lymphoma. Genes Dev 2006; 20:2096-2109.

67 Chan SM, Weng AP, Tibshirani R, Aster JC, Utz PJ: Notch signals positively regulate activity of the mTOR pathway in T-cell acute lymphoblastic leukemia. Blood 2007;110: 278-286.

68 Farnie G, Clarke RB: Mammary stem cells and breast cancer - role of Notch signalling. Stem Cell Rev 2007;3:169-175.

69 Farnie G, Clarke RB, Spence K, Pinnock N, Brennan K, Anderson NG, Bundred NJ: Novel cell culture technique for primary ductal carcinoma in situ: role of Notch and epidermal growth factor receptor signaling pathways. J Natl Cancer Inst 2007;99:616627.
70 Korkaya H, Wicha MS: Selective targeting of cancer stem cells: a new concept in cancer therapeutics. BioDrugs 2007;21:299-310.

71 Kuperwasser C, Dessain S, Bierbaum BE, Garnet D, Sperandio K, Gauvin GP, Naber SP, Weinberg RA, Rosenblatt M: A mouse model of human breast cancer metastasis to human bone. Cancer Res 2005;65:61306138.

72 Brisken C, Duss S: Stem cells and the stem cell niche in the breast: an integrated hormonal and developmental perspective. Stem Cell Rev 2007;3:147-156.

73 Boulanger CA, Mack DL, Booth BW, Smith $\mathrm{GH}$ : Interaction with the mammary microenvironment redirects spermatogenic cell fate in vivo. Proc Natl Acad Sci USA 2007; 104:3871-3876.

74 Karnoub AE, Dash AB, Vo AP, Sullivan A, Brooks MW, Bell GW, Richardson AL, Polyak K, Tubo R, Weinberg RA: Mesenchymal stem cells within tumour stroma promote breast cancer metastasis. Nature 2007; 449:557-563.

75 Kelly PN, Dakic A, Adams JM, Nutt SL, Strasser A: Tumor growth need not be driven by rare cancer stem cells. Science 2007;317: 337. 